\title{
Incidence of hepatic hamartomas in tuberous sclerosis
}

\author{
S Jóźwiak, M Pẹdich, P Rajszys, R Michalowicz
}

\begin{abstract}
Hepatic hamartomas were thought to be a rare finding in patients with tuberous sclerosis. The purpose of this study was to assess their incidence in children with tuberous sclerosis and to review the literature.

During 1984-90 we examined 51 children by ultrasonography; there were 25 boys and 26 girls. Their age ranged from 3 months to 18 years. Liver hamartomas were seen in 12 $(23.5 \%)$ of the children, more often in girls than boys (5:1). Their incidence increased with age reaching $45 \%$ in children over the age of 10 . They did not produce any symptoms of hepatic dysfunction.

Our study and review of reported cases prove that hepatic hamartomas are a common finding in patients with tuberous sclerosis and may be very helpful in providing a more accurate diagnosis and consequently help in genetic counselling.
\end{abstract}

\section{(Arch Dis Child 1992;67:1363-5)}

Child's Health Centre, Warsaw,

Poland,

Department of

Child Neurology

$S$ Jóźwiak

R Michalowicz

Department of Radiology $M$ Pedich

P Rajszys

Correspondence to:

Dr Sergiusz Jóźwiak,

Department of

Child Neurology

Child's Health Centre,

Al Dzieci Polskich 20,

04-736 Warszawa,

Poland.

Accepted 10 June 1992

Tuberous sclerosis is a genetic disorder with multiple hamartomas, autosomal dominant inheritance, variable expressivity, and high penetrance. Its expression may vary greatly with some individuals showing no clinical signs of the disorder and others manifesting severe seizure disorders, mental retardation, and involvement of multiorgan systems including skin, brain, heart, kidneys, retina, and liver.

The most common visceral lesions are renal angiomyolipomas, which have been studied extensively by others and are found in $52-89 \%$ of patients. 12

Hamartomas of the liver in association with tuberous sclerosis are usually found incidentally

Table 1 Ultrasonographic findings in 12 children and three parents with liver hamartomas associated with tuberous sclerosis

\begin{tabular}{|c|c|c|c|c|}
\hline $\begin{array}{l}\text { Case } \\
\text { No }\end{array}$ & $\begin{array}{l}\text { Age } \\
\text { (years) }\end{array}$ & Sex & Liver lesion & Associated kidney lesion \\
\hline $\begin{array}{l}1 \\
2\end{array}$ & $\begin{array}{l}12 \\
12\end{array}$ & $\begin{array}{l}\mathbf{F} \\
\mathbf{F}\end{array}$ & $\begin{array}{l}\text { Multiple, largest } 0.7 \mathrm{~cm} \\
\text { Multiple, } 0.5-0.7 \mathrm{~cm} \text {, calcification, }\end{array}$ & $\begin{array}{l}\text { AML } \\
\text { AML }\end{array}$ \\
\hline $\begin{array}{r}3 \\
4 \\
5 \\
6 \\
7 \\
8 \\
9 \\
10 \\
11 \\
12\end{array}$ & $\begin{array}{l}10 \\
1 \cdot 5 \\
8 \\
13 \\
5 \\
9 \\
0 \cdot 7 \\
6 \\
8 \\
13\end{array}$ & $\begin{array}{l}\mathbf{F} \\
\mathbf{M} \\
\mathbf{F} \\
\mathbf{F} \\
\mathbf{F} \\
\mathbf{F} \\
\mathbf{F} \\
\mathbf{M} \\
\mathbf{F} \\
\mathbf{F}\end{array}$ & $\begin{array}{l}\text { Single, calcification, right lobe } \\
\text { Single, } 0.6 \mathrm{~cm} \text {, left lobe } \\
\text { Multiple, } 0.5-0.7 \mathrm{~cm} \\
\text { Multiple, largest } 0.7 \mathrm{~cm} \\
\text { Multiple, } 0.5 \mathrm{~cm} \\
\text { Multiple, } 0.5-0.8 \mathrm{~cm} \\
\text { Multiple, } 0.5 \mathrm{~cm} \\
\text { Single, } 0.7 \mathrm{~cm}, \text { right lobe } \\
\text { Multiple, } 0.5-0.7 \mathrm{~cm} \\
\text { Multiple, largest } 0.8 \mathrm{~cm}\end{array}$ & $\begin{array}{l}\text { AML, cysts } \\
\text { None } \\
\text { None } \\
\text { AML } \\
\text { None } \\
\text { AML, clear cell sarcoma } \\
\text { AML } \\
\text { AML } \\
\text { AML, cysts } \\
\text { AML }\end{array}$ \\
\hline $\begin{array}{l}13 \\
14 \\
15\end{array}$ & $\begin{array}{l}35 \\
22 \\
41\end{array}$ & $\begin{array}{l}\mathbf{F} \\
\mathbf{M}\end{array}$ & $\begin{array}{l}\text { Multiple, largest } 2.5 \mathrm{~cm} \\
\text { Single, } 0.7 \mathrm{~cm} \text {, right lobe } \\
\text { Multiple, } 0.5-0.8 \mathrm{~cm}\end{array}$ & $\begin{array}{l}\text { AML } \\
\text { AML } \\
\text { None }\end{array}$ \\
\hline
\end{tabular}

AML = angiomyolipoma. on postmortem examination, ${ }^{34}$ with selective angiography, ${ }^{5-7}$ computed tomography, ${ }^{89}$ or by ultrasonography. ${ }^{10-12}$ The incidence of hepatic lesions, however, has been evaluated in only one large study. ${ }^{12}$

We evaluated the incidence of hepatic hamartomas in children with tuberous sclerosis and reviewed the literature on previously reported cases.

\section{Patients and methods}

During the period 1984-90 we examined 51 children by ultrasonography; there were 25 boys and 26 girls. The age of patients ranged from 3 months to 18 years (mean age 6.8 years). There were 20 patients under 5 years of age, 20 children between 5 and 10 years, and 11 patients over the age of 10 .

The diagnosis of tuberous sclerosis was established in all patients by careful history taking and examination of the skin, nails, hair, and eyes according to the Gomez criteria for tuberous sclerosis. ${ }^{13}$ Cerebral computed tomography and ultrasonography of the heart were also done.

Ultrasonographic examinations of the upper abdomen were performed with a sector scanner, using a 3.75 or $5 \mathrm{MHz}$ transducer to evaluate the liver, kidneys, pancreas, and spleen. Four parents with tuberous sclerosis were examined by the same method.

\section{Results}

Hepatic hamartomas were seen in $12(23.5 \%)$ of the 51 examined children. They were found more often in girls than boys $(5: 1)$ and their incidence increased with age.

Areas of increased echogenicity compared with the surrounding hepatic parenchyma were found in two out of the 20 children (10\%) below the age of 5 years (an 8 month old girl and a 1.5 year old boy), in five out of the 20 children $(25 \%)$ between 5 and 10 years, and in five out of the 11 patients $(45 \%)$ over the age of 10 . Usually, the hamartomas were multiple $(n=9)$ and localised in both liver lobes. They all measured from 0.5 to $0.8 \mathrm{~cm}$ in size. Calcification in these lesions was found in two girls aged 10 and 12 years (table 1 ).

In nine out of 12 children with liver involvement ultrasonography also revealed multiple bilateral angiomyolipomas of the kidneys. In two of these children renal angiomyolipomas coexisted with cysts and in one 9 year old girl, renal angiomyolipomas coexisted with a clear cell sarcoma. After several years of good health, 
during which this girl did not come for follow up examination, she developed a relapsing fever. Except for the hepatic hamartoma, ultrasound study of the kidneys showed a large tumour of $6 \times 6 \times 9 \mathrm{~cm}$ in the right kidney and bilateral, multiple angiomyolipomas. She underwent radical nephrectomy but died three months after surgical intervention.

In none of the children, with the exception of the girl with renal clear cell sarcoma, did we observe any clinical symptoms or signs of hepatic or renal dysfunction. The blood pressure and all biochemical tests including concentrations of electrolytes, serum creatinine, and uric acid and activities of alkaline phosphatase, glutamic oxaloacetic transaminase, and glutamic pyruvic transminase were within normal limits. There was no blood or protein in the urine.

Hepatic hamartomas were seen in three out of four parents with tuberous sclerosis: two women and one man. Both women, 22 and 35 years of age, demonstrated hepatic hamartomas coexisting with multiple renal angiomyolipomas. Similar changes, both hepatic and renal, were revealed in their daughters, 8 months and 12 years of age, respectively. Ultrasonographic examination of the 41 year old man showed multiple hepatic hamartomas and a normal picture of both kidneys.

\section{Discussion}

For many years hepatic hamartomas were regarded as an unusual finding in tuberous sclerosis. However, we have found 28 patients with tuberous sclerosis and liver involvement in the medical literature (table 2).

The incidence of hepatic lesions has been evaluated only in two reports. ${ }^{6}{ }^{12}$ Compton et al demonstrated vascular tumours of the liver with coeliac angiography in five out of eight patients; their ages were 10 months (two patients), 11.2 and 29 years. $^{6}$ In the study of Fleury et al hepatic hamartomas were revealed by ultrasonography in $13 \%$ of patients (three out of 23 ) under 16 years of age and in $23 \%$ (three out of 13) in the older patients. ${ }^{12}$

Our results prove that the incidence of

Table 2 Hepatic harmartoma: review of the literature (total 28: 19F/9M)

\begin{tabular}{|c|c|c|c|c|}
\hline $\begin{array}{l}\text { Authors } \\
\text { (in chronological order) }\end{array}$ & $\begin{array}{l}\text { No of } \\
\text { patients }\end{array}$ & Sex & $\begin{array}{l}\text { Age } \\
\text { (years) }\end{array}$ & $\begin{array}{l}\text { Diagnosis of } \\
\text { liver lesions }\end{array}$ \\
\hline $\begin{array}{l}\text { Kagan and Steckel }{ }^{10} \\
\text { Grasso } \text { et } a l^{4} \\
\text { Newmark } e t l^{8} \\
\text { Marsidi and Wise } \\
\text { Ilgren and Westmoreland }{ }^{78} \\
\text { Rosen et al }{ }^{7} \\
\text { Roberts } \text { et al } l^{19}\end{array}$ & $\begin{array}{l}1 \\
1 \\
1 \\
1 \\
1 \\
1 \\
5\end{array}$ & $\begin{array}{l}F \\
F \\
F \\
F \\
\text { F } \\
F \\
F \\
M \\
F \\
F \\
M \\
M \\
F \\
F \\
F \\
M \\
M \\
F \\
F \\
2 M / 4 F \\
F \\
M\end{array}$ & $\begin{array}{l}41 \\
25 \\
28 \\
25 \\
24 \\
22 \\
11 \\
10 / 12 \\
29 \\
24 \\
10 / 12 \\
11 \\
1 / 12 \\
52 \\
23 \\
21 \\
28 \\
26 \\
23 \\
42 \\
6-48 \\
10 \\
40\end{array}$ & $\begin{array}{l}\text { Neurilemmoblastomas } \\
\text { Lipomesenchymal tumours } \\
\text { AML, polycystic lesions } \\
\text { Hamartoma } \\
\text { Lipoma } \\
\text { Vascular abnormalities } \\
\text { Hamartoma } \\
\text { Hamartoma } \\
\text { Hamartoma } \\
\text { Hamartoma } \\
\text { Hamartoma } \\
\text { AML } \\
\text { Atypical, large hepatocytes } \\
\text { AML } \\
\text { Precapillary angiomas } \\
\text { AML } \\
\text { Fatty lesion, AML? } \\
\text { Lipomatous tumors, AML? } \\
\text { Lipomatous tumors, AML? } \\
\text { Lipomatous tumors, AML? } \\
\text { Harmartomas. Haemangiomas? } \\
\text { AML } \\
\text { Fibromas }\end{array}$ \\
\hline
\end{tabular}

AML-angiomyolipoma. hepatic hamartomas may be even higher, reaching $45 \%$ in children above 10 years of age.

In the reviewed literature hepatic hamartomas were found more often in females than males, with the ratio 19:9. In our study this predominance was even more apparent (5:1).

Hepatic hamartomas in tuberous sclerosis seem to be benign and asymptomatic. In contrast to renal lesions, hepatic hamartomas were not mentioned as a possible cause of death in patients with tuberous sclerosis in a large study of 355 patients at the Mayo Clinic. ${ }^{21}$

None of the children examined in our study had any manifestation of hepatic dysfunction. In the literature we could not find any description of hepatic manifestations in tuberous sclerosis patients with liver involvement except for one patient presented by Kristel and Sperber. ${ }^{20}$ These authors described a 10 year old girl with tuberous sclerosis who was examined after blunt abdominal trauma. Computed tomography and ultrasound showed a hepatic tumour in the left lobe, which enlarged during the next several months and forced them to carry out a hepatic lobectomy.

Histopathological examination of hepatic hamartoma was available in several cases. Hepatic angiomyolipomas were the most common tumours found in patients with tuberous sclerosis. ${ }^{10161820}$ The other reports also mentioned neurilemmoblastoma, ${ }^{14}$ lipomesenchymal tumour, ${ }^{15}$ hamartoma, ${ }^{3}$ and lipoma. ${ }^{17}$

Interestingly, haemangioma, the most common benign tumour of the liver was not seen in any of histopathologically examined patients with tuberous sclerosis.

Diagnosis of vascular hepatic tumours in tuberous sclerosis was suggested in several reports in angiographic ${ }^{6-8}$ and ultrasonographic studies. ${ }^{12}$ We suppose that angiographic findings in the liver of patients with tuberous sclerosis may resemble vascular expression of angiomyolipomas more than real haemangioma. Unfortunately, computed tomography of the liver was not performed in any of the aforementioned studies.

The ultrasonographic appearance of lipomatous masses cannot be easily differentiated from haemangioma. The pattern is not specific for angiomyolipomas, therefore, ultrasound studies should be supplemented by computed tomography. Contrast enhanced computed tomography is able to provide greater detail by demonstrating low density areas that represent fatty tissue.

We believe that the diagnosis of hepatic angiomyolipomas in our patients is highly probable. But as none of them presented symptoms of hepatic dysfunction, and, as patients with liver hamartomas in tuberous sclerosis seem to have a good prognosis, we decided not to perform computed tomography as a routine procedure. Ultrasonographic assessment of the liver should be performed together with kidney evaluation in follow up studies.

Roberts et al stressed a relationship between renal angiomyolipomas and hepatic tumours in patients with tuberous sclerosis. ${ }^{19}$ Their study of a group of 50 patients with renal angiomyo- 
lipomas revealed lipomatous tumours of the liver in five patients. Three of them were known to be affected with tuberous sclerosis.

Renal angiomyolipomas were found in $\mathbf{8 5 \%}$ (24/28) of tuberous sclerosis patients with liver involvement reported in the literature and in $75 \%$ $(9 / 12)$ of children in the presented study. However, these figures cannot prove that any relationship between renal and hepatic angiomyolipomas exists. In our experience renal angiomyolipomas appear before hepatic hamartomas and both develop with age. This evolution of the lesions may result in their frequent coexistence in older children and adults.

We conclude that liver hamartomas are a very valuable feature in the diagnosis of tuberous sclerosis, especially of formes frustes. In the absence of long term studies, periodic monitoring with hepatic and renal ultrasonography is recommended for all patients with tuberous sclerosis.

1 Narla LD, Slovis TL, Watts FB, Nigro M. The renal lesions of tuberosclerosis (cysts and angiomyolipoma)-screening with sonography and computerized tomography. Pediatr with sonography and
Radiol 1988;18:205-9.

2 Bell DG, King BF, Hattery RR, Charboneau JW, Hoffman AD, Houser OW. Imaging characteristics of tuberous

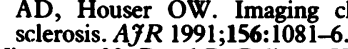

3 Viamonte M, Ravel R, Politano V, Bridges B. Angiographic findings in a patient with tuberous sclerosis. AfR 1966;98: 723-33.
4 Grasso S, Manusia M, Sciacca F. Unusual liver lesion in tuberous sclerosis. Arch Pathol Lab Med 1982;106:49.

5 Chonko AM, Weiss SM, Stein JH, Ferris TF. Renal involvement in tuberous sclerosis. Am F Med 1974;56:124-32.

6 Compton WR, Lester PD, Kyaw MM, Madsen JA. The abdominal angiographic spectrum of tuberous sclerosis. $A \mathcal{Y} R$ 1976;126:807-13.

7 Marsidi PJ, Wise HA. Tuberous sclerosis and angiomyolipomatous kidney conditions. Ohio State Medical foumal

8 Newmark H, Bhagwanani DG, Rishi US, Mellon WS, Hafeez $M$, Kant $N$. Tuberous sclerosis evaluated by computerized tomography. Computed Radiology 1982;6: 287-93.

9 Rosen RJ, Schlossberg P, Roven SJ, Rothberg M. Management of symptomatic renal angiomyolipomas by embolization. Urol Radiol 1984;6:196-200.

10 Kagan AR, Steckel RJ. Flank pain and hematuria in a child. Diagnostic oncology case study. AfR 1981;136:597-600.

11 Green JE, Adams GW, Shawker TH, Sax FL, Koeller DM, Zasloff MA. Hypertension and renal failure in a patient with tuberous sclerosis. South Med F 1990;83:451-4.

12 Fleury P, Smits N, van Baal S. The incidence of hepatic hamartomas in tuberous sclerosis. Evaluation by ultrahamartomas in tuberous sclerosis.

13 Gomez MR. Criteria for diagnosis. In: Gomez MR, ed. Tuberous sclerosis. New York: Raven Press, 1988:9-21.

14 Inglis K. Neurilemmoblastosis. The influence of intrinsic factors in disease when development of the body is abnormal. Am F Pathol 1950;26:521-36.

15 Cares RM. The tuberous sclerosis complex. I Neuropathol Exp Neurol 1958;17:247-54.

16 Perou ML, Gray PT. Mesenchymal hamartomas of the kidney. F Urol 1960;83:240-61.

17 Ramchand S, Ahmed Y, Baskerville L. Lipoma of the liver. Archives of Pathology 1970;90:331-3.

18 Ilgren EB, Westmoreland D. Tuberous sclerosis: unusual manifestations in four cases. $\mathcal{F}$ Clin Pathol 1984;37:272-8.

19 Roberts JL, Fishman EK, Hartman DS, Sanders R, Goodman Z, Siegelman SS. Lipomatous tumors of the liver: Goodman Z, Siegelman SS. Lipomatous tumors of the liver:

20 Kristal H, Sperber F. Hepatic angiomyolipoma in a tuberous sclerosis patient. Isr $\mathcal{Y}$ Med Sci 1989;25:412-4.

21 Shepherd CW, Gomez MR, Lie JT, Crowson CS. Causes of death in patients with tuberous sclerosis. Mayo Clin Proc 1991;66:792-6. 